CURRENT

Jurnal Kajian Akuntansi dan Bisnis Terkini

https://current.ejournal.unri.ac.id

\title{
EFEKTIVITAS PENGELOLAAN KEUANGAN DAERAH : PERAN MODERASI SISTEM PENGENDALIAN INTERN PEMERINTAH
}

\author{
Nana Santika ${ }^{1 *}$, Taufeni Taufik ${ }^{2}$, Devi Savitri ${ }^{3}$ \\ ${ }^{123}$ Program Studi Akuntansi, Fakultas Ekonomi dan Bisnis, Universitas Riau, Pekanbaru \\ *E-mail: nana.santika2678@student.unri.ac.id
}

\section{Keywords \\ Employee Performance, Regional Financial Accounting System, Human Resources Competence, Effectiveness of Regional Financial Management, Government Internal Control System.}

\section{Article informations}

Received:

2021-01-26

Accepted:

2021-08-02

Available Online:

2021-08-03

\begin{abstract}
This study aims to determine the effect of employee performance, regional financial accounting systems, and human resource competencies on the effectiveness of regional financial management which is moderated by the government's internal control system. This research was conducted at Pelalawan District $O P D$. The data used in this study are primary data that is questionnaire. The population in this study were employees who worked at the Regional Apparatus Organization in Pelalawan Regency. This study uses purposive sampling. Of 81respondent participated indicate that: Employee performance and the regional financial accounting system influences the effectiveness of regional financial management but Human resource competence does not affect the effectiveness of regional financial management. The government's internal control system can moderate the effect of employee performance, the regional financial accounting system and human resource on the effectiveness of regional financial management.
\end{abstract}

\section{PENDAHULUAN}

Efektivitas adalah ukuran berhasil atau tidaknya suatu organisasi mencapai tujuannnya. Efektivitas hanya melihat apakah suatu program atau kegiatan telah mencapai tujuan yang telah ditetapkan (Mardiasmo, 2009). Efektivitas pengelolaan keuangan daerah merupakan serangkaian kegiatan yang dilakukan oleh pemerintah daerah melalui perencanaan, pelaksanaan, penatausahaan, pertanggungjawaban, pelaporan, dan pengawasam keuangan daerah sesuai dengan batas waktu yang telah ditetapkan berdasarkan anggaran yang telah disediakan dalam rangka mencapai tujuan dan sasaran yang telah ditetapkan sesuai dengan peraturan perundang-undanga yang berlaku (Peraturan Pemerintah Nomor 21 Tahun 2010 Tentang Pengelolaan Keuangan Daerah, 2010).

Efektivitas Pengelolaan Keuangan Daerah dapat ditunjukkan oleh besarnya 
penyerapan anggaran pemerintah. Penyerapan anggaran yang tidak merata menunjukkan bahwa kurang efektifnya pengelolaan keuangan pemerintah. Seperti yang terjadi pemerintah Kabupaten Pelalawan, hinga awal bulan November tahun 2019 penyerapan APBD masih 51\% dari total anggaran 1,6 Triliun. Kondisi ini tentu jauh dari target yang semestinya yaitu 70\% pada bulan November 2019 (www.tribun.pekanbaru.com). Hal ini menyebabkan berbagai target kegiatan menjadi terlambat. Kemudian terlambatnya pengesahan perubahan APBD menyebabkan kegiatan yang dianggarkan di perubahan tidak terlaksana scara maksimal. Masih rendahnya presentase penyerapan anggaran dan gagalnya target pemerintah Kabupaten Pelalawan menyebabkan pemerintah ditutut untuk responsif dalam melaksanakan pengelolan keuangan daerah agar bisa berjalan secara efektif.

Penelitian penelitian terdahulu telah mengkaji berbagai penyebab tidak efektifnya pengelolaan keungan pada pemeintah. (Santosa, 2017) menyatakan bahwa kinerja pegawai mempengaruhi efektivitas pengelolaan keuangan pada pemintah. Pengukuran kinerja pegawai dilakukan dengan membandingkan target kinerja yang telah ditetetapkan dengan realisasinya dapat menjadi motivasi pegawai untuk mencapai target yang telah ditetapkan dengan cara menyelesaikan pekerjaan dengan tepat waktu. Perbandingan tersebut dapat diketahui oleh kinerja (perfomence gap) yang selanjutnya dianalisis untuk mengetahui penyebab ketidakberhasilan, sehingga dapat ditetapkan suatu strategi guna peningkatan kinerja dimasa mendatang (perfomence improvent) (Utami, 2017). Dari hasil pengukuran kinerja dapat disimpulkan tingkat keberhasilan dari target yang ditetapkan (Utami, 2017).

Hasil penelitian (Santosa, 2017) menunjukkan bahwa kinerja pegawai berpengaruh signifikan terhadap efektivitas pengelolaan keuangan daerah. Namun penelitain (Mardiana, 2011) menunjukkan bahwa kinerja pegawai tidak berpengaruh terhadap efektivitas pengelolaan keuangan daerah.

Selanjutnya yang mempengaruhi efektivitas pengelolaan keuangan daerah adalah sistem akuntansi keuangan daerah (Iskandar, 2017). Sistem Akuntansi Keuangan Daerah (SAKD) merupakan serangkaian prosedur mulai dari proses pengumpulan data, pencatatan pengihtisaran sampai dengan pelaporan keuangan dalam rangka pertanggungjawaban pelaksanaan APBD yang dilakukan secara manual atau menggunakan aplikasi computer (Peraturan Mentri Dalam Negri Nomor 21 Tahun 2011, Tentang Pedoman Pengelolaan Keuangan Daerah). Adanya tujuan dari penerapan sistem akuntansi keuangan daerah ini adalah selain untuk memberikan informasi keuangan, juga bertujuan untuk mengontrol seluruh kegiatan ekonomi didalam suatu emntitas pemerintah. Jika sistem akuntansi belum terpenuhi maka akan menghambat penyusunan laporan keuangan. Tujuan utama adanya 
kebijakan pengelolaan keuangan pada dasarnya adalah untuk mewujudkan tata kelola pemerintahan yang baik dan bersih (Good Govermence end Clean Govermence) beoriotasi pada hasil, profesionalitas, proporsionalitas dan menghasilkan laporan keuangan yang transparan dan akuntabel. Dengan adanya Sistem Akuntansi Keuangan Daerah (SAKD) diharapkan pengelolaan keuangan daerah dapat berjalan dengan efektif agar penatausahaan keuangan daerah memiliki akurasi dan akuntabilitas yang tinggi .

Penelitian tentang sistem akuntansi keuangan daerah sebelumnya pernah diteliti oleh (Santosa, 2017), hasil penelitian menunjukkan bahwa sistem akuntansi keuangan daerah berpengaruh signifikan terhadap efektivitas pengelolaan keuangan daerah. Namun penelitain (Sukmawati \& Nurfitriani, 2019), mengatakan bahwa sistem akuntansi keuangan daerah tidak berpengaruh terhadap efektivitas pengelolaan keuangan daerah.

Sumber daya manusia juga berperan penting dalam pencapaian pengelolaan keuangan daerah (Iskandar, 2017). Agar pengelolaan keuangan berjalan efektif dan Laporan Keuangan Pemerintah Daerah berkualitas dibutuhkan sumber daya manusia yang memahami dan kompeten dalam akuntansi pemerintahan, baik dan buruknya pengelolaan keuangan daerah disebabkan oleh sumber daya manusia yang ada pada pemerintah tersebut, hal ini disebabkan karena sumber daya manusia adalah komponen utama yang berfungsi dalam menjalankan pemerintah agar pengelolaan keuangan pemerintah daerah dapat berjalan dengan efektif (Utami, 2017).

Penelitian tentang kompetensi sumber daya manusia sebelumnya pernah diteliti oleh (Iskandar, 2017) dan (Gusmayanti, 2018), hasil penelitian menunjukkan bahwa kompetensi sumber daya manusia berpengaruh signifikan terhadap efektivitas pengelolaan keuangan daerah. Dalam penelitain (Justika, 2020) mengatakan bahwa kompetensi sumber daya manusia tidak berpengaruh terhadap efektivitas pengelolaan keuangan daerah.

Ketidak konsistenan hasil penelitian penelitian diatas ternyata ada hal lain yang memperkuat atau memperlemah setiap variabel. Sistem pengendalian intern merupakan salah satu unsur penting yang dapat mempengaruhi pengelolaan keuangan daerah. Dalam Peraturan Nomor 60 Tahun 2008, sistem pengendalian internal yang selanjutnya disingkat SPIP, adalah sistem pengendalian intern yang diselengarakan secara menyeluruh di lingkungan pemerintah pusat dan pemerintah daerah. Dimana pasal 2 ayat 3 menyelaskan bahwa tujuan sistem pengendalian intern pemerintah adalah untuk memberikan keyakinan yang memadai bagi tercapainya efektivitas dan efesiensi pencapaian tujuan penyelenggaraan pemerintah Negara, keandalan pelaporan keuangan, pengamatan aset Negara dan ketaatan pada peraturan perundang-undangan. Lembaga pemerintah sebaiknya memiliki suatu sistem 
pengendalian agar dapat meminimalisirkan resiko yang ada, walaupun aktifitas dalam pengelolaan keuangan daerah bagus namun sistem pengendalian internnya lemah maka dapat memperlemah aktivitas untuk mencapai aktivitasnya. Jika aktivitas dalam pengelolaan keuangan daerah diiringi dengan pengawas intern yang baik maka pengelolaan keuangan daerah dapat berjalan secara efektif (Santosa, 2017).

Berdasarkan hasil penelitian (Sismatupang, 2017) menunjukkan sistem pengendalian intern berpengaruh positif dan signifikan terhadap efektifitas pengelolaan keuangan daerah pada dinas pendapatan dan pengelolaan keuangan daerah kota Gorontalo. Peningkatan sistem pengendalian intern pemerintah yang semakin baik maka akan dibarengi oleh efektifitas pengelolaan keuangan daerah yang semakin baik Sistem pengendalian intern akan turun meningkatkan efektifitas pengelolaan keuangan daerah itu sendiri. Sedangkan penelitian (Mita, 2020), menunjukkan sistem pengendalian intern pemerintah tidak berpengaruh terhadap pengelolaan keuangan pemerntah kota Pekanbaru.

Berdasarkan hal diatas penelitian ini bertujuan untuk mengembangkan yang dilakukan oleh (Tanzelina, 2017). Berbeda dengan dengan penelitian sebelumnya, penelitian ini juga menguji kinerja pegawai dalam menentukan efektivitas pengelolaan keuangan daerah serta dmenguji sistem pengendalian intern pemerintah sebagai variable moderasi. Keunikan penelitian ini terletak pada moderasi sistem pengendalian intern yang masih jarang digunakan dalam menganalisis efektivitas pengelolaan keuangan daerah. Penelitian ini juga dikhususkan dilakukan pada Pemerintah Kabupaten Pelalawan.

\section{PENGEMBANGAN HIPOTESIS}

\section{Pengaruh Kinerja Pegawai terhadap Efektivitas Pengelolaan Keuangan Daerah}

Kinerja pegawai dapat dilihat dari prestasi kerja, kejujuran dalam hal melaporkan hasil kerja kepada atasan menurut keadaan yang sesunguhnya. Kinerja pegawai juga dapat dilihat dari kreatifitas seperti berusaha dalam mencari tatacara yang baru mencapai dayaguna dan daya hasil untuk entitasnya. Apabila dalam pengelolaan keuangan pegawai memiliki kinerja yang tinggi maka akan meningkatkan efektivitas pengelolaan keuangan daerah (Utami, 2015).

Dalam pengelolaan keuangan daerah pegawai merupakan motor penggerak yang mengelola keuangan daerah. Baik atau buruknya pengelolaan keuangan tergantung pada Sumber Daya Manusianya (SDM), dalam hal ini ditunjukkan melalui cara kerja atau pun hasil kerja dari pegawai tersebut. Hermana (2015) membuktikan bahwa Kinerja Pegawai dapat mempengaruhi efektivitas keuangan daerah. Pegawai yang memiliki kinerja yang tinggi 
sangat menunjang pencapaian efektivitas pengelolaan keuangan daerah maupun dalam pelaksanaan kebijakan keuangan daerah. Kondisi tersebut menunjukkan bahwa efektivitas pengelolaan keuangan daerah yang dilaksanakan optimal. Dengan adanya kinerja pegawai yang maksimal maka akan meningkatkan efektivitas pengelolaan keuangan daerah. (Santosa, 2017).

(Mardiasmo,2009) mengemukakan kinerja program berhubungan dengan akuntabilitas publik, karena pemerintah sebgai pengemban amanat masyarakat bertanggungjawab atas kinerja yang telah dilakukannya. Hal tersebut karena pemerintah berkewajiban untuk mengelola program pembanggunan dalam rangka menjalankan pemerintah. Efektivitas dari pemerintah daerah terwujud bila tujuan pemerintah tersebut dapat tercapai sesuai dengan kebutuhan yang direncanakan. Sesuai denga Pemendagri Nomor 13 Tahun 2006, efektivitas pencapaian hasil program dengan target yang telah ditentukan, yaitu dengan cara membandingkan keluaran dengan hasil. Dengan adanya kinerja pegawai yang maksimal (bekerja sesuai dengan waktu yang ditentukan dan membuat laporan keuangan sesuai dengan standar akuntansi), maka akan meningkatkan efektivitas pengelolaan keuangan daerah.

Hal ini sepedapat dengan penelitian (Sufiani, 2019), membuktikan dalam penelitiannya bahwa Kinerja Pegawai memiliki pengaruh yang signifikan terhadap Efektivitas Pengelolaan Keuangan Daerah. Berdasarkan uraian diatas dapat dirumukan suatu hipotesis sebagai berikut:

\section{$\mathrm{H}_{1}$ : Kinerja Pegawai berpengaruh terhadap Efektivitas Pengelolaan Keuangan Daerah.}

\section{Pengaruh Sistem Akuntansi Keuangan Daerah terhadap Efektivitas Pengelolaan Keuangan Daerah}

Sistem akuntansi keuangan daerah merupakan pencatatan, penggolongan, penafsiran, peringkasan transaksi atas kejadian keuangan serta pelaporan dalam rangka pelaksanaan APBD (KepMendagri N0.29 Tahun 2002 Pasal 70 Ayat 1). PP No 71 Tahun 2010 menetapkan bahwa SAP dengan dasar akuntansi berbasis akrual. Pemendagri No.64 Tahun 2013 juga mengatakan bahwa daerah menetapkan sistem akuntansi pemerintah dengan dasar akuntansi berbasis akrual untuk mengelola keuangan daerah yang efektif. Dalam struktur pemerintah daerah, satuan kerja merupakan entitas akuntansi yang wajib melakukan pencatatan atas transaksi-transaksi yang terjadi lingkungan satuan kerja. Kegiatan akuntansi pada satuan kerja meliputi pencatatan atas pendapatan, asset, belanja, dana selain kas. Proses tersebut dilaksanakan oleh Pejabat Penatausahaan Keuangan (PPK) berdasarkan dokumen- 
dokumen sumber yang diserahkan oleh bendahara.

Dengan adanya laporan realsasi anggaran, dapat menyediakan informasi kepada para pengguna laporan tentang indikasi apakah sumber daya ekonomi yang diperoleh dan digunakan (PP No. 71 Tahun 2010). Sistem akuntansi keuangan daerah terdiri dari prosedurprosedur yang harus dipenuhi oleh pihak pengelolaan keuangan yang ada didalamnya. Sistem ini terdiri dari beberapa proses seperti pencatatan, pengihtisaran, sampai dengan pelaporan keuangan, pengelolan keuangan (seperti kepala pimpinan, bendahara) yang ada didalam instansi pemerintah dituntut untuk menjalankan prosedur ini sesuai ketentuannya. Ini berarti bahwa secara tidak lansung sistem akuntansi keuangan daerah ini menuntut pengelolaan keuangan untuk taat kepada kepala prosedur yang ada. Apabila prosedur-prosedur ini dijalankan sesuai ketentuan yang telah diatur maka sistem akuntansi keuangan daerah akan menghasilkan informasi keuangan yang baik, cermat dan transparan. Hal ini akan dapat membantu dalam efektivitas pengelolaan keuangan daerah (Gusmayanti, 2018).

Penelitian yang dilakukan oleh (Gusmayanti,2018) membuktikan bahwa Sistem Akuntansi Keuangan Daerah dapat mempengaruhi Efektivitas Pengelolaan Keuangan Daerah. Berdasarkan uraian diatas dapat dirumuskan hipotesis sebagai berikut:

\section{$\mathrm{H}_{2}$ : Sistem Akuntansi Keuangan Daerah berpengaruh terhadap Efektivitas Pengelolaan Keuangan Daerah.}

\section{Pengaruh Kompetensi Sumber Daya Manusia terhadap Efektivitas Pengelolaan Keuangan Daerah}

Sumber daya manusia mempunyai pengaruh yang besar dalam membantu meningkatkan efektivitas pengelolaan keuangan daerah. Karena didalam suatu instansi, sumber daya manusia merupakan penggerak suatu instansi tersebut. Oleh karenanya, sumber daya yang bekerja di instansi tersebut harus memiliki pengetahuan, kemampuan dan perilaku individu dalam melaksanakan suatu pekerjaan. Sumber daya manusia tersebut harus mempunyai pengetahuan tentang penggangaran, pelaksanaan, dan pertanggungjawaban pengelolaan keuangan yang baik, mempunyai pengetahuan dibidang pelaporan keuangan sesuai dengan standar yang berlaku. Kemudian sumber daya manusia tersebut juga harus memiliki kemampuan dan keterampilan. Misalnya standar perilaku para pegawai dalam memiliki metode kerja yang dianggap lebih efektif dan efesien. Apabila pengelolaan keuangan daerah dijalankan oleh sumber daya manusia yang kompeten maka hal ini dapat meningkatkan efetivitas pengelolaan keuangan daerah. 
Hal ini sependapat penelitian yang pernah dilakukan oleh (Iskandar, 2017), yang membuktikan bahwa kompetensi sumber daya manusia berpengaruh terhadap efektivitas pengelolaan keuangan daerah. Berdasarkan hal diatas maka dihipotesiskan :

\section{H3 $_{3}$ : Kompetensi Sumber Daya Manusia berpengaruh terhadap Efektivitas Pengelolaan}

\section{Keuangan Daerah.}

\section{Pengaruh Kinerja Pegawai Terhadap Efektivitas Pengelolaan Keuangan Daerah dengan Sistem Pengendalian Intern Pemerintah sebagai Variabel Moderating}

Menurut PP No. 06 tahun 2008 tentang pedoman evaluasi penyelenggaraan pemerintah daerah, pemerintah berkewajiban mengevaluasi kinerja pemerintah daerah untuk mengetahui keberhasilan penyelenggaraan pemerintah daerah dalam memanfaatkan hak yang diperoleh daerah dengan capaian keluaran dan hasil yang telah direncanakan. Tujuan utama dilaksanakan evaluasi adalah untuk menilai kinerja penyelengaraan pemerintah daerah dalam upaya peningkatan kinerja yang mendukung pencapaian tujuan otonomi daerah berdasarkan prinsip tata pemerintahan yang baik.

Kinerja pegawai mempunyai peranan penting dalam mengelola keuangan daerah, oleh karena itu kinerja pegawai harus diperhatikan dalam mengelola keuangan daerah. Dengan adanya sistem pengendalian intern pemerintah sangat membantu mewujudkan tercapainya peningkatan kinerja dalam suatu pemerintah daerah (Simatupang, 2017). Kinerja pegawai memiliki peranan penting bagi suatu pemerintah daerah karenaa tercapai tidaknya tujuan pemerintah daerah bergantung bagi kinerja pegawainya. Hal tersebut mengandung arti agar pengelolaan keuangan daerah dapat tercapai dengan efektif. Sistem pengendalian intern pemerintah dalam hal ini digunakan oleh instansi pemerintah untuk menjamin bahwa sumber daya manusia yang ada di instansi pemerintah digunakan secara efektif, dan efesien terhadap pencapaian tujuan instansi. Pencapaian kinerja yang tinggi dikarenakan peneraapan sistem pengendalian intern pemerintah secara efektif. Kegagalan instansi pemerintah dalam mencapai pengelolaan keuangaan daerah yang efektif dapat terjadi karena adanya kelemahan pada salah satu atau beberapa tahap dalam sistem pengendalian intern. Kinerja pegawai akan ditujukan dengan seberapa besar efektifnya dalam pengelolaan keuangan daerah dan sistem pengendalian intern pemerintah dapat memberikan keyakinan memadai dalam mencapai tujuan pengelolaan keuangan daerah agar dapat berjalan secara efektif (Simatupang, 2017).

Penelitian tentang kinerja pegawai sebelumnya pernah diteliti oleh (Sismatupang, 2017), hasil penelitian menunjuan bahwa kinerja pegawai berpengaruh signifikan terhadap efektivitas pengelolaan keuangan daerah di OPD Kabupaten Indargiri Hilir. 


\section{$\mathrm{H}_{4}$ : Sistem Pengendalian Intern Pemerintah Memoderasi Hubungan antar Kinerja Pegawai Terhadap Efektivitas Pengelolaan Keuangan Daerah.}

\section{Pengaruh Sistem Akuntansi Keuangan Daerah Terhadap Efektivitas Pengelolaan Keuangan Daerah dengan Sistem Pengendalian Intern Pemerintah sebagai Variabel Moderating}

Untuk menciptakan pengelolaan keuangan yang efektif maka harus ada sistem yang baik juga. Oleh karna itu pemerintah daerah dapat membuat peraturan atau kebijakan mengenai sistem akuntansi keuangan sesuai dengan yang dibutuhkan. Namun sistem akuntansi keuangan daerah harus disusun dengan berpedoman pada prinsip pengendalian intern sesuai dengan peraturan pemerintah yang mengatur tentang pengendalian intern dan peraturan pemerintah tentang standar akuntansi pemerintah .

Dalam penelitian ini pengendalian internal pemerintah sebagai variable moderating dapat memperkuat atau memperlemah hubungan antara variable independen dengan variable dependen. Pengendalian internal pemerintah sebagai variable moderating dapat memperkuat dan memperlemah hubungan antara system akuntansi keuangan daerah dengan efektivitas pengelolaan keuangan daerah. Semakin baik penerapan sistem akuntansi keuangan daerah maka efektivitas pengelolaan keuanga daerah semakin baik, sebaliknya system akuntansi keuangan daerah yg buruk mengakibatkan efektivitas pengelolaan keuangan daerah juga semakin baik. (Tanzelina, 2017)

Hal ini dibuktikan oleh penelitian yang dilakukan (Tanzelina, 2017) dimana sistem pengendalian intern pemerintah memoderasi hubungan sistem akuntansi keuangan daerah dengan efektivitas pengelolaan keuangan daerah.

\section{H5 : Sistem Pengendalian Intern Pemerintah Memoderasi Hubungan antar Sistem Akuntansi Keuangan Daerah Terhadap Efektivitas Pengelolaan Keuangan Daerah.}

Pengaruh Kompetensi Sumber Daya Manusia Terhadap Efektivitas Pengelolaan Keuangan Daerah dengan Sistem Pengendalian Intern Pemerintah sebagai Variabel Moderating

Pada instansi pemerintah, agar pengelolaan keuangan berjalam secara efektif dan laporan keuangan pemerintah daerah yang berkualitas dibutuhkan sumber daya manusia yang memahami dan kompeten dalam akuntansi pemerintah, keuangan daerah bahkan organisasional tentang pemerintah (Selemba, 2014). 
Pada umumnya semakin tinggi kompetensi sumber daya manusia maka kualitas informasi keuangan yang dihasilkan akan semakin baik. Sumber daya manusia yang paham akan akuntansi pemerintah dan memiliki pengalaman pada pengelolaan keuangan daerah yang dibutuhkan untuk dapat menghasilkan efektivitas dalam pengelolaan keuangan daerah (Liza, 2014). Penerapan pengendalian intern yang baik akan memberikan efektivitas pengelolaan keuangan daerah, sistem pengendalian intern yang baik tentu tidak akan berguna jika tidak didukung dengan sumber daya manusia yang berkompeten. Dengan demikian, dengan adanya sumber daya manusia yang kompeten serta diperkuat dengan sistem pengendalian intern pemerintah yang memadai maka akan mengahasilkan efektivitas pengelolaan keuangan daerah.

Menurut (Yola, 2017) pengendalian intern didefenisikan sebagai suatu proses yang dipengaruhi oleh sumber daya manusia yang dirancang untuk membantu organisasi mencapai suatu tujuan tertentu. Sistem pengendalian intern pemerintah merupakan suatu cara untuk mengarahkan, mengawasi dan mengukur sumber daya manusia organisasi serta berperan penting dalam mencegah dan mendeteksi penggelapan. Pengendalian intern terdiri atas kebijakan dan prosedur yang digunakan dalam mencapai tujuan dan sasaran yang telah direncanakan. Penerapan pengendalian intern yang baik akan memberikan efektivitas pengelolaan keuangan daerah, sistem pengendalian intern yang baik tentu tidak akan berguna jika tidak didukung dengan sumber daya manusia yang berkompeten. Dengan demikian, dengan adanya sumber daya manusia yang kompeten serta diperkuat dengan sistem pengendalian intern pemerintah yang memadai maka akan mengahasilkan efektivitas pengelolaan keuangan daerah .

Apabila sistem pengendalian intern pemerintah dilaksanakan, maka keandalan pelaporan keuangan efektivitas dan efesian serta kepatuhan terhadap peraturan perundangundangan bias tercapai sehinga penggelolaan keuangan daerah akan terlaksana secara efektif.

Hasil penelitian yang dilakukan (Tanzelina, 2017) menunjukkan sistem pengendalian intern pemerintah memoderasi hubungan kompetensi sumber daya manusia daerah dengan efektivitas pengelolaan keuangan daerah.

\section{H6 : Sistem Pengendalian Intern Pemerintah Memoderasi Hubungan antara Kompetensi Sumber Daya Manusia Terhadap Efektivitas Pengelolaan Keuangan Daerah.}




\section{METODE PENELITIAN}

\section{Populasi dan Sampel}

Populasi dalam penelitian ini adalah pegawai yang bekerja pada Organisasi Perangkat Daerah di Kabupaten Pelalawan yang berjumlah 27 OPD. Penelitian ini menggunakan purposive sampling Jumlah sampel dalam penelitian ini adalah 81 responden, dari setiap OPD akan diambil 3 responden dengan kriteria Kepala OPD, Kasubag Keuangan dan Bendahara.

\section{Teknik Pengumpulan Data}

Pengumpulan data akan dilakukan melalui survey kuesioner yang diambil dari penelitian terdahulu. Koesioner adalah daftar pertanyaan yang telah dirumuskan sebelumnya yang akan responden jawab, biasanya dalam alternative yang didefenisikan dengan jelas" (Sekaran, 2017).

\section{Metode Analisis Data}

Penelitian ini mempunyai enam hipotesis yang diuji dengan menggunakan bantuan software SPSS (Statistical Product and Service Solution). Untuk menguji hipotesis 1, hipotesis 2 dan hipotesis 3 digunakan model analisis regresi berganda. Sedangkan hipotesis 4, hipotesis 5 dan hipotesis 6 digunakan MRA, dalam penelitian ini dapat dirumuskan sebagai berikut :

$$
\begin{aligned}
& Y=\alpha+\beta_{1} X_{1}+\beta_{2} X_{2}+\beta_{3} X_{3}+e \\
& Y=\alpha+\beta_{1} X_{1}+\beta_{3} X_{1} * Z+\varepsilon \\
& Y=\alpha+\beta_{3} X_{2}+\beta_{3} X_{2} * Z+\varepsilon \\
& Y=\alpha+\beta_{3} X_{3}+\beta_{3} X_{3} * Z+\varepsilon
\end{aligned}
$$

\section{Dimana :}

$\mathrm{Y} \quad=$ Efektivitas Pengelolaan Keuangan Daerah

$\alpha \quad=$ Konstanta

$\beta=$ Besaran koefisien regresi dari masing-masing variable

$\mathrm{X}_{1} \quad=$ Kinerja Pegawai

$\mathrm{X}_{2} \quad=$ Sistem Akuntansi Keuangan Daerah

$\mathrm{X}_{3}=$ Kompetensi Sumber Daya Manusia

e $=$ error

\section{HASIL PENELITIAN DAN PEMBAHASAN}

Hasil survei kuesioner dalam penelitian ini menunjukkan dari 81 kuesioner yang telah disebarkan, sebanyak 75 kuesioner (92,59\%) yang direspon, kuesioner yang tidak direspon sebanyak 6 kuesioner $(7,41 \%)$, dan kuesioner yang dapat diolah sebanyak kuesioner $(92,59 \%)$. 
Ringkasan mengenai karakteristik responden dapat dilihat dalam tabel 1

\section{Tabel 1}

\section{Karakteristik Responden Penelitian}

\begin{tabular}{|c|c|c|}
\hline Keterangan & $\begin{array}{l}\text { Jumlah } \\
\text { (orang) }\end{array}$ & Persentase (\%) \\
\hline \multicolumn{3}{|l|}{ Jenis Kelamin: } \\
\hline a. Pria & 32 & $42,67 \%$ \\
\hline b. Wanita & 43 & $57,33 \%$ \\
\hline Total & 75 & $100 \%$ \\
\hline \multicolumn{3}{|l|}{ Pendidikan Terakhir: } \\
\hline a. SMA & 4 & $5,33 \%$ \\
\hline b. D3 & 7 & $9,33 \%$ \\
\hline c. $\mathrm{S} 1$ & 57 & $76 \%$ \\
\hline d. S2 & 7 & $9,33 \%$ \\
\hline e. S3 & 0 & $\%$ \\
\hline Total & 75 & $100 \%$ \\
\hline \multicolumn{3}{|l|}{ Jabatan: } \\
\hline a. Kepala OPD & 25 & $33,33 \%$ \\
\hline b. Kasubag Keuangan & 25 & $33,33 \%$ \\
\hline c. Bendahara & 25 & $33.33 \%$ \\
\hline Total & 75 & $100 \%$ \\
\hline \multicolumn{3}{|l|}{ Lama Bekerja: } \\
\hline a. $>5$ Tahun & 3 & $4 \%$ \\
\hline b. 5 - 10 Tahun & 8 & $10,67 \%$ \\
\hline c. $<$ Tahun & 64 & $85,33 \%$ \\
\hline Total & 75 & $\%$ \\
\hline
\end{tabular}

Sumber: Data Olahan (2020)

\section{Hasil Statistik Deskriptif}

Tabel berikut menunjukkan hasil statistik deskriptif berdasarkan data yang diperoleh dari responden.

\section{Tabel 2.}

\section{Hasil Statistik Deskriptif}

\begin{tabular}{lrrrrr} 
& N & Minimum & Maximum & Mean & Std. Deviation \\
\hline Total_X1 & 75 & 28 & 40 & 34,27 & 2,177 \\
Total_X2 & 75 & 28 & 35 & 30,92 & 1,964 \\
Total_X3 & 75 & 22 & 30 & 26,17 & 1,996 \\
Total_Y & 75 & 26 & 35 & 30,36 & 2,166 \\
Total_Z & 75 & 47 & 60 & 52,37 & 2,944 \\
\hline
\end{tabular}

Sumber: Olah data dengan menggunakan SPSS (2020)

Dari tabel 2 diatas dapat dilihat bahwa Efektivitas Pengelolaan Keuangan Daerah 
(Y) dengan nilai minimun 26, nilai maksimum sebesar 35. Nilai tengah atau mean adalah 30,36 dengan standar deviasi 2,166. Kinerja Pegawai (X1) dengan nilai minimun 28, nilai maksimum sebesar 40. Nilai tengah atau mean adalah 34,27 dengan standar deviasi 2,177. Sistem Akuntansi Keuangan Daerah (X2) dengan nilai minimun 28, nilai maksimum sebesar 35. Nilai tengah atau mean adalah 30,92 dengan standar deviasi 1,964. Kompetensi Sumber Daya Manusia (X3) dengan nilai minimun 22, nilai maksimum sebesar 30. Nilai tengah atau mean adalah 26,17 dengan standar deviasi 1,996. Sistem Pengendalian Intern Pemerintah (Z) dengan nilai minimun 47 , nilai maksimum sebesar 60 . Nilai tengah atau mean adalah 52,37 dengan standar deviasi 2,944 .

\section{Hasil Uji Kualitas Data}

Hasil uji kualitas data menggunakan uji validitas dan reliabilitas yang menggunakan korelasi pearson dan Cronbach alpha yang dapat dilihat pada tabel 3.

\section{Tabel 3}

\section{Hasil Uji Validitas dan Reliabilitas}

\begin{tabular}{|c|c|c|c|c|c|}
\hline Keterangan & r Hitung & r Tabel & Kesimpulan & $\begin{array}{c}\text { Cronbach } \\
\text { Alpha }\end{array}$ & Ket \\
\hline $\begin{array}{c}\text { Efektivitas Pengelolaan } \\
\text { Keuangan Daerah }\end{array}$ & $0,3554-707$ & 0,227 & Valid & 0,646 & Reliabel \\
\hline Kinerja Pegawai & $0,380-0,714$ & 0,227 & Valid & 0,677 & Reliabel \\
\hline $\begin{array}{c}\text { Sistem Akuntansi Keuangan } \\
\text { Daerah }\end{array}$ & $0,412-0,669$ & 0,227 & Valid & 0,611 & Reliabel \\
\hline $\begin{array}{c}\text { Kompetensi Sumber Daya } \\
\text { Manusia }\end{array}$ & $0,560-0,760$ & 0,227 & Valid & 0,719 & Reliabel \\
\hline $\begin{array}{l}\text { Sistem Pengendalian Intern } \\
\text { Pemerintah }\end{array}$ & $0,415-0,563$ & 0,227 & Valid & 0,678 & Reliabel \\
\hline
\end{tabular}

Sumber: Olah data dengan menggunakan SPSS (2020)

Dari tabel 3 dapat disimpulkan bahwa validitas dan reliabilitas terpenuhi karena nilai $\mathrm{r}$ hitung > $\mathrm{r}$ tabel dan Cronbach alpha > 0,6.

\section{Hasil Uji Analisis Regresi Linear Berganda}

Berikut tabel ini disajikan untuk mengetahui hubungan antara variabel bebas terhadap variabel terikat dalam penelitian ini: 


\section{Tabel 4}

\section{Hasil Analisi Regresi Linera Berganda Hipotesis Satu, Dua dan Tiga.}

\begin{tabular}{llrrrrr}
\hline & \multicolumn{5}{c}{ Unstandardized } & \multicolumn{2}{c}{ Standardized } \\
Coefficients & \\
Model & & B & Std. Error & \multicolumn{1}{c}{ Beta } & \multicolumn{1}{c}{ T } & Sig. \\
\hline 1 & (Constant) & 7,796 & 4,550 & & 1,713 &, 091 \\
& Total_X1 &, 359 &, 108 &, 360 & 3,315 &, 001 \\
& Total_X2 &, 282 &, 121 &, 256 & 2,338 &, 022 \\
& Total_X3 &, 060 &, 122 &, 055 &, 490 &, 626 \\
\hline
\end{tabular}

Sumber: Olah data dengan menggunakan SPSS (2020)

Berdasarkan tabel 4 diatas dapat diperoleh hasil uji t dan tingkat signifikan antara variabel bebas terhadap variabel terikat dalam penelitian ini

\section{Pengaruh Kinerja Pegawai terhadap Efektivitas Pengelolaan Keuangan Daerah}

Dari tabel tersebut, dapat dilihat bahwa $\mathrm{t}$ hitung $>\mathrm{t}$ tabel yaitu 3,315 >1,994 dan signifikansi 0,001 < 0,05. Dengan demikian, $\mathrm{H}_{0}$ ditolak dan $\mathrm{H}_{1}$ diterima. Dapat disimpulkan bahwa Kinerja Pegawai berpengaruh terhadap Efektivitas Pengelolaaan Keuangan Daerah Kabupaten Pelalawan.

Dengan diterima hipotesis ini membuktikan bahwa kinerja pegawai merupakan faktor penting dalam meningkatkan efektivitas pengelolaan keuangan daerah. Semakin tinggi kinerja pegawai maka semakin efektif pengelolaan keuangan pemerintah Kabupaten Pelalawan. Kinerja pegawai mempunyai peranan penting dalam mengelola keuangan daerah, oleh sebab itu kinerja pegawai harus diperhatikan dalam mengelola keuangan daerah (Utami, 2017). Hal ini dikarenakan agar pengelolaan keuangan daerah mendapatkan hasil yang maksimal. Kinerja pegawai pada dasarnya terjadi setelah pegawai merasa adanya kepuasa atau memperoleh hasil dari pekerjaannya karena kebutuhannya terpenuhi, makanya apabila kebutuhan pengawasan belum terpenuhi maka kepuasan kerja tidak akan tercapai dan kinerj pegawai akan sulit terbentuk dengan optimal.

Hal ini sependapat dengan penelitian (Sufiani, 2019) yang membuktikan dalam bahwa Kinerja Pegawai memiliki pengaruh yang signifikan terhadap Efektivitas Pengelolaan Keuangan Daerah. Namun berbeda dengan penelitian (Mardiana, 2011) dan yang menyatakan bahwa Kinerja Pegawai tidak Berpengaruh terhadap Efektivitas Pengelolaan Keuangan Daerah. 
Pengaruh Sistem Akuntansi Keuangan Daerah terhadap Efektivitas Pengelolaan

\section{Keuangan Daerah}

Dari tabel 4 tersebut, dapat dilihat bahwa t hitung $>\mathrm{t}$ tabel yaitu $2.338>1,994$ dan signifikansi 0,022 <0,05. Dengan demikian, $\mathrm{H}_{0}$ ditolak dan $\mathbf{H}_{2}$ diterima. Dapat disimpulkan bahwa Sistem Akuntansi Keuangan Daerah berpengaruh terhadap Efektivitas Pengelolaan Keuangan Daerah Kabupaten Pelalawan. Semakin baik sistem akuntansi keuangan daerah maka semakin efektif pengelolaan keuangan daerah pada Kabupaten Pelalawan.

Tujuan dari sistem akuntansi keuangan daerah adalah untuk menciptakan transparansi dan akuntabilitas. Sistem akuntansi keuangan daerah harus mampu mengontrol kegiatan ekonomi yang ada disuatu entitas. Sistem akuntansi keuangan daerah dituntut untuk mengendalikan seluruh kegitan ekonomi didalam suatu entitas bejalan sesuai dengan prosedur yang telah berlaku, wajar dan transparan. Apabila sistem akuntansi keuangan daerah telah berjalan sesuai dengan yang diharapkan maka sistem akuntansi keuangan daerah akan mampu meningkatkan efektivitas pengelolaan keuangan daerah.

Penelitian ini sejalan dengan dengan penelitian (Santosa, 2017) yang menunjukkan bahwa sistem akuntansi keuangan daerah berpengaruh signifikan terhadap efektivitas pengelolaan keuangan daerah. Sedangkan dalam penelitain (Sismatupang, 2017), mengatakan bahwa sistem akuntansi keuangan daerah tidak berpengaruh terhadap efektivitas pengelolaan keuangan daerah.

\section{Pengaruh Kompetensi Sumber Daya Manusia terhadap Efektivitas Pengelolaan Keuangan}

\section{Daerah}

Dari tabel 4 tersebut, dapat dilihat bahwa $\mathrm{t}$ hitung $<\mathrm{t}$ tabel yaitu $0,490<1,994$ dan signifikansi 0,626>0,05. Dengan demikian, Ho diterima dan $\mathrm{H}_{3}$ ditolak. Dapat disimpulkan bahwa Kompetensi Sumber Daya Manusia tidak berpengaruh terhadap Efektivitas Pengelolaan Keuangan Daerah Kabupaten Pelalawan.

Kompetensi sumber daya adalah kompetensi yang berhubungan dengan pengetahuan, keterampilan, kemampuan dan karakteristik keperibadian yang mempengaruhi secara lansung terhadap kinerjanya”. Dengan demikian dapat disimpulkan bahwa kompetensi sumber daya manusia adalah kemampuan seseorang atau individu suatu organisasi dalam melaksanakan pekerjaannya dengan dilandasi atas keterampilan dan pengetahuan.

Dari hasil penelitian ini menunjukkan bahwa meskipun di OPD Kabupaten Pelalawan telah terdapat sumber daya manusia tetapi mereka belum kompeten di bidangnya sehinga pemerintah belum mampu menjadikan pengelolaan keuangan daerah itu berjalan secara 
efektif. Seharusnya sumber daya manusia mempunyai pengaruh yang besar dalam membantu meningkatkan efektivitas pengelolaan keuangan daerah, karena didalam suatu instansi, sumber daya manusia yang menjalankan dan menggerakan suatu instansi tersebut.

Hal ini tentu bukanlah hal yang bersifat mutlak dalam mencerminkan kondisi yang sebenarnya. Hasil penelitian ini sejalan dengan penelitian yang dilakukan oleh (Sismatupang, 2017) mengatakan bahwa Kompetensi Sumber Daya Manusia tidak berpengaruh terhadap Efektivitas Pengelolaan Keuangan Daerah. Sedangkan penelitian (Iskandar, 2017) mengatakan bahwa Kompetensi Sumber Daya Manusia berpengaruh terhadap Efektivitas Pengelolaan Keuangan Daerah

Pengaruh Kinerja Pegawai terhadap Efektivitas Pengelolaan Keuangan Daerah dengan Sistem Pengendalian Intern Pemerintah sebagai Variabel Moderating

Hasil pengujian moderasi dapat dilihat pada tabel 5

\section{Tabel 5}

Hasil Uji Moderated Regression Analysis Hipotesis keempat

\begin{tabular}{|c|c|c|c|c|c|c|}
\hline \multirow{2}{*}{\multicolumn{2}{|c|}{ Model }} & \multicolumn{2}{|c|}{ Unstandardized Coefficients } & \multirow{2}{*}{$\begin{array}{c}\begin{array}{c}\text { Standardized } \\
\text { Coefficients }\end{array} \\
\text { Beta }\end{array}$} & \multirow[b]{2}{*}{$\mathrm{t}$} & \multirow[b]{2}{*}{ Sig. } \\
\hline & & $\mathrm{B}$ & Std. Error & & & \\
\hline \multirow[t]{4}{*}{1} & (Constant) & $-15,403$ & 8,548 & & $-1,802$ & ,076 \\
\hline & $\mathrm{x} 1$ &,- 101 & ,052 & $-3,068$ & $-1,928$ & ,058 \\
\hline & $\mathrm{z}$ &,- 063 & ,034 & $-2,596$ & $-1,854$ & ,068 \\
\hline & $\ln x 1 . z$ & 3,766 & 1,783 & 5,406 & 2,111 & 038 \\
\hline
\end{tabular}

Sumber: Olah data dengan menggunakan SPSS (2020)

Dari tabel tersebut, dapat dilihat bahwa $\mathrm{t}$ hitung $>\mathrm{t}$ tabel yaitu 2,111 >1,994 dan signifikansi 0,038<0,05. Dengan demikian, $\mathrm{H}_{0}$ ditolak dan $\mathbf{H}_{4}$ diterima. Dapat disimpulkan bahwa Sistem Pengendalian Intern Pemerintah dapat memoderasi Kinerja Pegawai Terhadap Efektivitas Pengelolaan Keuangan Daerah Kabupaten Pelalawan .

Kinerja pegawai mempunyai peranan penting dalam mengelola efektivitas keuangan daerah, oleh karena itu kinerja pegawai harus diperhatikan dalam mengelola keuangan daerah. Dengan adanya sistem pengendalian intern pemerintah sangat membantu mewujudkan tercapainya peningkatan kinerja dalam suatu pemerintah daerah. Kinerja pegawai memiliki peranan penting bagi suatu pemerintah daerah karenaa tercapai tidaknya tujuan pemerintah daerah bergantung bagi kinerja pegawainya. Hal tersebut mengandung arti agar pengelolaan keuangan daerah dapat tercapai dengan efektif. Bahwa sistem pengendalian 
intern pemerintah dalam hal ini adalah digunakan oleh instansi pemerintah untuk menjamin bahwa sumber daya manusia yang ada diinstansi pemerintah digunakan secara efektif, dan efesien terhadap pencapaian tujuan instansi. Pencapaian kinerja yang tinggi dikarenakan peneraapan sistem pengendalian intern pemerintah secara efektif. Kegagalan instansi pemerintah dalam mencapai pengelolaan keuangaan daerah yang efektif dapat terjadi karena adanya kelemahan pada salah satu atau beberapa tahap dalam sistem pengendalian intern. Kinerja pegawai akan ditujukan dengan seberapa besar efektifnya dalam pengelolaan keuangan daerah dan sistem pengendalian intern pemerintah dapat memberikan keyakinan memadai dalam mencapai tujuan pengelolaan keuangan daerah agar dapat berjalan secara efektif.

Hasil penelitian ini sejalan dengan hasil penelitian yang dilakukan oleh (Santosa, 2017) yang menunjukkan bahwa sistem pengendalian intern pemerintah memoderasi pengaruh kinerja pegawai terhadap efektivitas pengelolaan keuangan daerah di OPD Kabupaten Indargiri Hilir, sedangkan penelitian (Mita, 2020) menyatakan bahwa sistem pengendalian intern pemerintah tidak memoderasi pengaruh dari kinerja pegawai terhadap efektivitas pengelolaan keuangan daerah.

Pengaruh Sistem Akuntansi Keuangan Daerah terhadap Efektivitas Pengelolaan Keuangan Daerah dengan Sistem Pengendalian Intern Pemerintah sebagai Variabel Moderating

Hasil pengujian hipotesis 5 dapat dilihat pada tabel 6

\section{Tabel 6}

\section{Hasil Moderated Regression Analysis Hipotesis Kelima}

\begin{tabular}{|c|c|c|c|c|c|c|}
\hline \multirow{2}{*}{\multicolumn{2}{|c|}{ Model }} & Unstandardized & Coefficients & $\begin{array}{l}\text { Standardized } \\
\text { Coefficients }\end{array}$ & & \\
\hline & & $B$ & Std. Error & Beta & $\mathrm{t}$ & Sig. \\
\hline 1 & (Constant) & $-22,084$ & 8,373 & & $-2,637$ & ,010 \\
\hline & $x 2$ &,- 165 & .058 & $-4,526$ & $-2,838$ & ,006 \\
\hline & Z &,- 091 & .034 & $-3,723$ & $-2,663$ & 010 \\
\hline & $\ln \times 2 . z$ & 5,283 & 1.785 & 7.531 & 2.959 & .004 \\
\hline
\end{tabular}

Sumber: Olah data dengan menggunakan SPSS (2020)

Dari tabel 3 tersebut, dapat dilihat bahwa $\mathrm{t}$ hitung $>\mathrm{t}$ tabel yaitu 2,959>1,994 dan signifikansi 0,004 $<0,05$. Dengan demikian, $\mathrm{H}_{0}$ ditolak dan $\mathbf{H}_{5}$ diterima. Dapat disimpulkan bahwa Sistem Pengendalian Intern Pemerintah dapat memoderasi pengaruh Sistem Akuntansi Keuangan Daerah terhadap Efektivitas Pengelolaan Keuangan Daerah.

Keuangan daerah harus dikelola dengan baik agar semua hak dan kewajiban daerah 
yang dapat dinilai dengan uang dapat dimanfaatkan semaksimal mungkin untuk kepentingan daerah (Justika, 2010). Dalam Peraturan Pemerintah Nomor 58 Tahun 2005 menyatakan bahwa keuangan daerah harus dikelola secara tertib, taat peraturan perundang-undangan, efesien, ekonomi, efektif transparan dan bertanggungjawab dengan memperhatikan azas keadilan, kepatuhan dan manfaat untuk masyarakat.

Untuk menciptakan pengelolaan keuangan yang efektif maka harus ada sistem yang baik juga (Mita, 2020). Oleh karena itu pemerintah daerah dapat membuat peraturan atau kebijakan mengenai sistem akuntansi keuangan sesuai dengan yang dibutuhkan. Namun sistem akuntansi keuangan daerah harus disusun dengan berpedoman pada prinsip pengendalian intern sesuai dengan peraturan pemerintah yang mengatur tentang pengendalian intern dan peraturan pemerintah tentang standar akuntansi pemerintah .

Hasil ini sejalan dengan hasil penelitian yang dilakukan oleh (Tanzelina, 2017) dimana sistem pengendalian intern pemerintah memoderasi hubungan sistem akuntansi keuangan daerah dengan efektivitas pengelolaan keuangan daerah. Sedangkan penelitian (Mita, 2020) menyatakan bahwa sistem pengendalian intern pemerintah tidak memoderasi hubungan sistem akuntansi keuangan daerah dengan efektivitas pengelolaan keuangan daerah.

Pengaruh Kompetensi Sumber Daya Manusia terhadap Efektivitas Pengelolaan Keuangan Daerah dengan Sistem Pengendalian Intern Pemerintah sebagai Variabel Moderating

Hasil pengujian hipotesis 6 dapat dilihat pada tabel 7.

\section{Tabel 7}

\section{Hasil Moderated Regression Analysis Hipotesis Keenam}

\begin{tabular}{cccccc}
\hline & Unstandardized & Coefficient & Stundardized & Coefficient & \\
\hline Model & B & Std. Error & Beta & T & Sig \\
(Constant) & $-17,832$ & 9,584 & & $-1,861$ &, 067 \\
x3 &,- 095 &, 046 & $-2,635$ & $-2,073$ &, 042 \\
Z &,- 088 &, 046 & $-3,594$ & $-1,905$ &, 061 \\
$\ln 3 \mathrm{z}$ & 7,715 & 3,592 & 5,668 & 2,148 &, 035 \\
\hline
\end{tabular}

Sumber: Olah data dengan menggunakan SPSS (2020)

Dari tabel 7 tersebut, dapat dilihat bahwa $t$ hitung $>\mathrm{t}$ tabel yaitu 2,148 $>1,994$ dan signifikansi $0,035<0,05$. Dengan demikian, $\mathrm{H}_{0}$ ditolak dan $\mathbf{H}_{6}$ diterima. Dapat disimpulkan bahwa apakah Sistem Pengendalian Intern Pemerintah dapat memoderasi pengaruh Kompetensi Sumber Daya Manusia terhadap Efektivitas Pengelolaan Keuangan Daerah Kabupaten Pelalawan.

Pengendalian intern merupakan sebagai suatu proses yang dipengaruhi oleh sumber 
daya manusia yang dirancang untuk membantu organisasi mencapai suatu dalam tujuan tertentu. Sistem pengendalian intern pemerintah adalah suatu cara untuk mengarahkan, mengawasi dan mengukur sumber daya manusia organisasi serta berperan penting dalam mencegah dan mendeteksi penggelapan. Pengendalian intern terdiri atas kebijakan dan prosedur yang digunakan dalam mencapai tujuan dan sasaran yang telah direncanakan (Gebyvia \& Taufeni, 2020).

Penerapan pengendalian intern yang baik akan memberikan efektivitas pengelolaan keuangan daerah, sistem pengendalian intern yang baik tentu tidak akan berguna jika tidak didukung dengan sumber daya manusia yang berkompeten (Sari \& Bella, 2017). Dengan demikian, dengan adanya sumber daya manusia yang kompeten serta diperkuat dengan sistem pengendalian intern pemerintah yang memadai maka akan mengahasilkan efektivitas pengelolaan keuangan daerah.

Hal ini dibuktikan oleh penelitian yang dilakukan (Tanzelina, 2017) dimana sistem pengendalian intern pemerintah memoderasi hubungan kompetensi sumber daya manusia daerah dengan efektivitas pengelolaan keuangan daerah. Sedangkan penelitian (Mita, 2020) menyatakan sistem pengendalian intern pemerintah tidak memoderasi hubungan kompetensi sumber daya manusia daerah dengan efektivitas pengelolaan keuangan daerah.

\section{SIMPULAN}

Dari hasil penelitian ini dapat disimpulkan bahwa kinerja pegawai dan sistem akuntansi keuangan daerah berpengaruh terhadap efektivitas pengelolaan keuangan daerah pada OPD Pemerintah Kabupaten Pelalawan. Sedangkan kompetensi sumber daya manusia tidak berpengaruh terhadap efektivitas pengelolaan keuangan daerah, dan sistem pengendalian intern pemerintah memoderasi hubungan kinerja pegawai, sistem akuntansi keuangan daerah dan kompetensi sumber daya manusia terhadap efektivitas pengelolaan keuangan daerah.

Penelitian ini memiliki keterbatasan yaitu peneliti tidak melakukan wawancara lansung kepada responden, karena mengingat kesibukan responden dan peneltian ini hanya menggunakan objek peneltian pada OPD Kabupaten Pelalawan saja, sehinga belum dapat memberikan gambaran yang lebih luas. Kemudian dalam penelian ini penulis hanya menggunakan variabel system pengendalian intern pemerintah sebagai variabel moderating. Diduga masih ada faktor lain yang dapat menjadi variabel moderasi seperti motivasi, budidaya organisasi, penekanan anggran dan sebagainya. 
Oleh sebab itu penelitian ini menyarankan bagi penelitian selanjutnya dapat mengembangkan penelitian dengan menguji variabel dan menambahkan metode wawancara untuk mendapatkan informasi yang lebih akurat. Penelitian ini memiliki kontribusi bagi Pemerintah Kabupaten Pelalawan agar dapat meningkatkan sumber daya manusia dengan memberikan pelatihan serta meningkatkan implementasi system pengendalian intern agar dapat meningkatkan efektivitas pengelolaan keuangan pemerintah.

\section{REFERENSI}

Gebyvia, S., \& Taufeni, T. \& J. (2020). Pengaruh Kompetensi aparatur, Teknologi Informasi, Pengendalian Akuntansi dan Pelaporan terhadap Kinerja instansi Pemerintah (Studi OPD Kota Pekanbaru). Current Jurnal Kajian Akuntansi Dan Bisnis Terkini, 1.

Gusmayanti, S, I. (2018). Pengaruh Pengawasan Fungsional, Sistem Pengendalian Intern Pemerintah dan sistem akuntansi Keuangan Daerah (studi pada Kabupaten Kampar). Skripsi Universitas Riau.

Halim, A. (2004). Manajemen Keuangan Daerah Edisi Revisi. UUP AMP YPKN.

Iskandar, J. (2017). Pengaruh Sistem Pengendalian Intern Pemerintah, Kompetensi Sumber Daya Manusia, dan Pengawasan Fungsional Terhadap Efektivitas Pengelolaan Keuangan Daerah (Studi Pada Pemerintah Kota Pekanbaru). Jom FEKON, 2.

Justika, Z. (2020). Determinasi Kalitas Laporan Keuangan Pemerintah Daerah (Study Pada OPD Pemerintah Kota Pekanbaru. Current Jurnal Kajian Akuntansi Dan Bisnis Terkini, 1 .

Mardiana, D. (2011). Pengaruh Kinerja Pegawai Dan Pengawasan Fungsional Terhadap Efektivitas Pengelolaan Keuangan Daerah. Universitas Komputer Indonesia.

Mardiasmo. (2009). Akuntansi Sektor Publik. Andi Offset.

Mita, S. (2020). Determinasi Efektivitas Pengelolaan Keuangan Badan Layanan Umum (BLUD): Dimoderasi Sistem Pengendalian Intern Pemerintah. Current Jurnal Kajian Akuntansi Dan Bisnis Terkini, 2.

Peraturan Mentri Dalam Negri Nomor 21 Tahun 2011, tentang Pedoman Pengelolaan Keuangan Daerah.

Peraturan Pemerintah Nomor 21 Tahun 2010 tentang Pengelolaan Keuangan Daerah, (2010).

Peraturan Pemerintah Nomor 59 Tahun 2007.tentang Pengelolaan Keuangan Daerah.

Santosa, P. (2017). Pengaruh Kinerja Pegawai, Sistem Pengendalian Intern Pemerintah dan dan Sistem Akuntansi Keuangan Daerah Terhadap Efektivitas Pengelolaan Keuangan Daerah (Studi pada Kabupaten Indragiri Hilir). Skripsi. Universitas Riau. 
Sari, M., \& Bella, D. (2017). Pengaruh Sistem Pengendalian Intern Pemerintah dan Kompetensi Sumber Daya Manusia Terhadap Efektivitas Pengelolaan Keuangan Daerah (Studi Pada pemerintah Kota Surabaya). Jurnal ISSN: 2337 - 4349.

Sismatupang, M. (2017). Pengaruh Sistem Pengendalian intern Pemerintah, Sistem Akuntansi Keuangan Daerah Dan Kompetensi Sumber Daya Manusia. JOM Fekon, 4.

Sufiani. (2019). Pengaruh Kinerja Pegawai, Komitmen Organisasi, Sistem Pengendalian Intern pemerintah, Kompetensi Sumber Daya Manusia, Pengawasan Dungsional Dan Sistem Akuntansi Keuangan Daerah Terhadap Efektivitas Pengelolaan Keuangan Daerah. JOM FEB, 6.

Sukmawati, F., \& Nurfitriani, A. (2019). Pengaruh Transparansi dan Akuntabilitas terhadap Pengelolaan Keuangan Desa ( Studi pada Pemerintah Desa di Kabupaten Garut ). Jurnal Ilmiah Bisnis, Pasar Modal, Dan UMKM, 2(1), 52-66.

Tanzelina, D. (2017). Pengaruh akuntansi keuangan daerah dan kompeteni sumber daya Manusia Terhadap Efektivitas Pengelolaan Keuangan Daerah Dengan Sistem Pengendalian Intern sebagai Variabel Moderating. Jom FEKON. Universitas Riau, 2.

Utami, D. (2017). Pengaruh Kinerja Pegawai, Sistem Pengendalian Intern Pemerintah dan Sistem Akuntansi Keuangan Daerah Terhadap Efektivitas Pengelolaan Keuangan Daerah. Universitas Diponegoro.

\section{www.tribun.pekanbaru.com.}

Yola, F. (2017). Pengaruh Sistem Pengendalian Intern Pemerintah, Kompetensi Sumber Daya Manusia, dan Pemahaman atas Sistem Akuntansi Keuangan Daerah Terhadap Efektivitas Pengelolaan Keuangan Daerah. Skripsi. Universitas Riau. 